\title{
Behind the Mask:
}

\section{Revealing the True Face of Corporate Citizenship}

\section{Dirk Matten \\ Andrew Crane \\ Wendy Chapple}

ABSTRACT. This paper traces the development of corporate citizenship as a way of framing business and society relations, and critically examines the content of contemporary understandings of the term. These conventional views of corporate citizenship are argued to contribute little or nothing to existing notions of corporate social responsibility and corporate philanthropy. The paper then proposes a new direction, which particularly exposes the element of "citizenship". Being a political concept, citizenship can only be reasonably understood from that theoretical angle. This suggests that citizenship consists of a bundle of rights conventionally granted and protected by governments of states. However, the more that governmental power and sovereignty have come under threat, the more that relevant political functions have gradually shifted towards the corporate sphere - and it is at this point where "corporate" involvement into "citizenship" becomes an issue. Consequently, "corporate citizens" are substantially more than fellow members of the same community who cosily rub shoulders with other fellow citizens while bravely respecting those other citizens' rights and living up to their own responsibility as corporations - as the conventional rhetoric wants us to believe. Behind this relatively innocuous mask then, the true face of corporate citizenship suggests that the corporate role in contemporary citizenship is far more profound, and ultimately in need of urgent reappraisal.

KEY WORDS: business and government, corporate citizenship, corporate social responsibility, globalization, human rights, stakeholder theory

Dirk Matten is a Senior Research Fellow at the International Centre for Corporate Social Responsibility (ICCSR) at the Nottingham University Business School. Andrew Crane is a Senior Lecturer in Business Ethics at ICCSR and Wendy Chapple is the Deputy Director of ICCSR.

\section{Introduction}

This paper critically examines the rise and the content of the term corporate citizenship (CC), and asks how far it really embodies a new concept or new ideas. We first discuss the emergence of $\mathrm{CC}$ as new way of framing businesssociety relations, and outline two common perspectives on $\mathrm{CC}$ in the extant literature. We then develop a third, extended view of the concept that starts from the "citizenship" element of CC. We argue that, apart from one or two exceptions (e.g. Wood and Logsdon, 2001), this has been largely ignored in the still growing body of literature. Hence, starting from this notion of citizenship, we develop a conceptual framework for $\mathrm{CC}$ that reflects the shifting role of corporations in society during the last decade, and ultimately conceptualises a political role for the corporation in society. We suggest, however, that the face of current conceptions of $\mathrm{CC}$ as found in the literature, and as expressed by corporations and consultants, may actually serve to obscure this new role for the corporation, and in so far as new institutional arrangements are masked by this terminology, preclude a critical examination of business-society relations.

\section{Corporate citizenship in context: Conceptual frameworks for business-society relations}

As CC represents a progression within a longer tradition in conceptualising business and society relations, it is important to first examine the legacy of these concepts. The most popular concept to date, and essentially the building 
block of the modern business-society relations literature, is corporate social responsibility (CSR). CSR first arose in the 1950s, however it was in the late 1970s that the academic debate really started to form (Carroll, 1999). One of the founding definitions of the modern concept of CSR is the much-cited four-part model of CSR by Carroll (Carroll, 1979; see further Carroll and Buchholtz, 2000). According to this model, the corporation has four types of responsibilities: first, the economic responsibility to be profitable; and second, the legal responsibility to abide by the laws of the respective society. These two aspects are the mandatory part of business responsibility. The third responsibility is ethical, and obliges corporations to do what is right, just and fair even when business is not compelled to do so by the legal framework. Rather than being mandatory, the issues linked to the ethical responsibilities should lead to voluntary action by corporations, but are - as Carroll puts it "expected" from business. These "ethical" responsibilities, one could argue, have been the most debated ones, and much of the controversy in business-society relations have focused on these responsibilities. The fourth area of responsibility is labelled philanthropic and describes those activities "desired" by society, such as contributing resources to various kinds of social, educational, recreational or cultural purposes. Again, similar to "ethical" responsibilities, this fourth area of CSR is not mandatory and merely "should" be done by companies, although is not necessarily "expected". It is these latter two areas which are central to the area of study of CSR, since they differentiate corporate behaviour from mere compliance, but also are the most controversial due to the normative nature of these two forms of responsibility.

Other writers have focused on the nature and scope of CSR and have attempted to map the boundaries of responsibility of the firm. Wood (1991) defines business and society relations as being "interwoven rather than being distinct entities" and hence, societal expectations have direct influence in the shaping of CSR. Wood argues that this interrelatedness stems from 3 distinct levels of social responsibility within the firm - institutional, societal, and managerial - and it is these that shape the relationship between business and society. Hence, much of the seminal work on CSR was largely normative, in nature with the main focus being on the definition of the boundaries of responsibility of business. More recently, certain strains of the literature have attempted to address more pragmatic concerns. The corporate social performance (CSP) literature, for example, attempts to model and measure social responsibility in terms of performance, and a fertile stream of literature has attempted to draw out the relationships between social and financial performance (for an overview, see Wartick and Cochran, 1985; and McWilliams and Siegel, 2000).

The concept has not changed significantly beyond this definition. The second overarching framework we regard as important to mention, stakeholder theory, attempts to operationalise these responsibilities to an ill-defined "society" by identifying specific constituencies. Rather than looking at responsibilities, stakeholder theory, as initially brought forward by Edward Freeman (1984), starts by looking at potential groups in society and analyses the relation of the firm to these groups. By this it transcends the limits of managerial capitalism and its focus on shareholders as the most important group. On the contrary, stakeholder theory claims that the corporation has a responsibility to all those groups who are harmed by, or benefit from, the company and/or whose rights will be affected either positively or negatively (Evan and Freeman, 1993). Much of the wide acceptance of stakeholder thinking can be credited to its plausibility, based on descriptive and instrumental arguments (Donaldson and Preston, 1995) - that is, that managers appear to consider particular groups rather than society as a whole (descriptive); and that by doing so, performance might be improved (instrumental). However, according to Donaldson and Preston (1995), the central notion of stakeholder theory is normative, in that corporations actually have a moral obligation to all stakeholders (Gibson, 2000; Wijnberg, 2000). Thus stakeholder theory can be seen as a necessary but not sufficient condition for social responsibility. Stakeholder theory helps to identify concrete groups in society to which a 
firm has responsibilities, and by its reflection on Kantian thinking (Evan and Freeman, 1993), specifically provides a basis for legitimising and prioritising stakeholder influence on corporate decisions. Therefore, stakeholder theory can be seen as a necessary process in the operationalisation of CSR, as a complimentary rather than conflicting body of literature.

However, these concepts to date have still been largely normative in tone, both in answering the question of why, and to what extent, the voluntary involvement of corporations in society should take place. As such they generally were expressions of a rather critical attitude towards business and the debate never really transcended the ideological divide between business oriented "capitalist" thinkers (Milton Friedman being the textbook example) and "critical", "liberal" or "socialist" proponents of a stronger responsibility for the corporation in society.

In practice, there were many barriers to the implementation of CSR and stakeholder theory. The 1980s of "Reaganomics" and "Thatcherism" reinvigorated and legitimated the principle of the "market" and of "competition" as generally applicable to most business situations and introduced this economic approach to all stakeholder relations. Consequently, ethical or philanthropic responsibilities were not judged under the criterion of certain ethical values or social duties but under the clear perspective of corporate interests. Therefore, "investing" in social, ethical or philanthropic causes was increasingly deemed to be acceptable as long as it added to the bottom line (see Stroup and Neubert, 1987; Burke and Logsdon, 1996). Consequently, we might suggest that the traditional normative aspects of concepts of CSR, CSP and stakeholder theory were not in very strong demand in the business community, although much of the rhetorical and practical dimensions persevered. Moreover, from the 1990 s onward, the new terminology of corporate citizenship began to increasingly compete with and replace these extant notions in the realms of management theory and practice.

\section{Why a new term?}

One might ask why this new label of "corporate citizenship" has surfaced, and the old terminology of "stakeholder management" and "corporate social responsibility" has been deemed to some extent inappropriate. First, as Van Luijk (2001) has pointed out, industry has never been completely happy with the language of business ethics. The underlying inference of both the terms "business ethics" and "corporate social responsibility" implies that "ethics" or "responsibility" are concepts which are not present in business, or even worse, which are opposed to business. They were terms used by many proponents in the sense of reminding business of something additional they should or even must do. "Citizenship" on the other hand, has a rather different connotation for business. CC can be said to highlight the fact that the corporation sees or recaptures - it's rightful place in society, next to other "citizens", with whom the corporation forms a community. Citizenship then focuses on rights and responsibilities of all members of the community, which are mutually interlinked and dependant on each other (Waddell, 2000).

Second, it is clear from reviewing the wealth of literature and citations on $\mathrm{CC}$ that the terminology has been very much driven by practitioners, including managers, consultants and the popular business press. Rather than accepting the exhortations of academics and critics to become more "socially responsible", corporations simply chose to set their own agenda based around being a "good corporate citizen". Interestingly, the mushrooming of $\mathrm{CC}$ rhetoric in business has precipitated a rush of interest in academia and elsewhere. Hence, we have seen the emergence of articles and books on $\mathrm{CC}$, the establishment of new academic research centres focused on CC, as well as the launch of the dedicated Journal of Corporate Citizenship.

It is evident, however, that despite the addition of the CC term to the debate surrounding the social role of business, its usage has been far from consistent, and we might suggest, not at all clear. In the following sections, we shall therefore examine this usage, and in so doing, delineate three different perspectives on CC evident in the 
literature. Of these, two are largely conventional views based on CSR, whilst one, we suggest, offers an extended view which goes beyond existing conceptions of CSR. These different views, as we shall see, imply significantly social roles and responsibilities for business.

\section{A critical analysis of contemporary framings of corporate citizenship}

In the following we will critically analyse the conventional use of $\mathrm{CC}$ in literature and thereby examine the content and potential implications of this new concept as it currently stands. We will start with what we will call the "limited view of CC", before proceeding to what we refer to as the "equivalent view of CC".

\section{Limited view of corporate citizenship}

Initially, CC was, and in many respects still is, used to identify the philanthropic role and responsibilities the firm voluntarily undertakes in the local community, such as charitable donations. Carroll (1991) for example identifies "being a good corporate citizen" with a specific element of CSR, namely philanthropic responsibilities, identified as his fourth level of CSR. Accordingly, Carroll (1991) places CC at the top level of his CSR pyramid, suggesting that it is a discretionary activity beyond that which is expected of business. CC in this respect is regarded as a choice to "put something back" into the community, but is merely "desired" by the community rather than representing an ethical injunction of any kind - and as a result is, according to Carroll (1991, p. 42) "less important than the other three categories". For the firm, CC is generally seen therefore as fuelled by issues of self-interest - including the insight that a stable social, environmental, and political environment ensures profitable business (cf. Windsor, 2001; Wood and Logsdon, 2001). Following from this self-interest driven approach is a considerable amount of literature which discusses CC as manifest in specific investment decisions into the firms social environment
(Warhurst, 2001). Following the language of corporate finance there is talk of "social investing" (Waddock, 2001) in order to build up "social capital" (cf. the papers in Habisch et al., 2001) or "reputational capital" (Fombrun et al., 2000), all of which ultimately help to improve the economic performance or organisational performance of the corporation (Bolino et al., 2002). This approach ultimately sees the new contribution of CC to the debate in its basically economic character as an approach of long-term profit maximization as a result of (enlightened) self-interest (Seitz, 2002, pp. 61f.).

We refrain at this point from commenting on the use of $\mathrm{CC}$ in this limited sense from a normative perspective. In the context of this paper we would rather like to take up the question whether this limited view of CC really justifies the invention and usage of a new terminology. Neither the element of self-interest in corporate philanthrophy, nor the investment aspect of social engagement are elements that are completely new and have not been discussed in the literature on CSR or stakeholder theory before. Apart from that, there seems to be no common understanding about the definition of $\mathrm{CC}$, and qualifications such as "good" $\mathrm{CC}$ even underline the elusive nature of the "limited view of CC". Furthermore, there is only very poor reference to the fact that this new concept of business and society makes usage of the term "citizenship". Apart from the occasional reference to shared rights and duties with other members of society, there is no explicit explanation of the term "citizenship". Though there might be good reasons from the business viewpoint to reframe social involvement, the literature on CC discussed in this section does not provide convincing evidence for the necessity of a new terminology.

\section{Equivalent view of corporate citizenship}

The second use of the term is more general in scope, and is essentially a conflation of $\mathrm{CC}$ with existing concepts of CSR. The most striking example for this use of $\mathrm{CC}$ is probably Carroll himself who, in a paper entitled "The four faces 
of corporate citizenship" (Carroll, 1998), defines CC exactly the same way as he defined CSR two decades ago (Carroll, 1979; Pinkston and Carroll, 1994). This approach has been taken up by several authors, though in some cases by using slightly different phrasing (e.g. Ulrich, 2000). So, for instance, Andriof and McIntosh talk of corporate "societal" responsibility but use it synonymously with CSR - which does not particularly further the unambiguous understanding of CC (Andriof and McIntosh, 2001). $\mathrm{Or}$, in a number of recent papers, Maignan and colleagues (Maignan et al., 1999; Maignan and Ferrell, 2000, 2001) have defined CC as "the extent to which businesses meet the economic, legal, ethical and discretionary responsibilities imposed on them by their stakeholders". This is largely synonymous with the Carroll (1991) definition of CSR, albeit with a slight refocusing of emphasis towards the meeting of responsibilities as opposed to the responsibilities themselves. Thus, CC is essentially a performanceoriented reconceptualisation of CSR (similar to Davenport, 2000), perhaps reflecting the prominence of CC in practitioner discourse.

One of the problems in conceptualising CC is that many authors present a certain view of the debate in business and society relations so far and then attribute certain "new" issues and developments to this new label. Thus, "corporate citizenship" just functions as a new, as it were, combination of letters for certain ideas without any serious reflection on the notion of "citizenship" and its potentially new meaning. So, for instance, Birch regards $\mathrm{CC}$ as an innovation to the CSR concept in that CC causes business to see itself as part of the public culture whereas CSR is - according to his perception - more concerned with social responsibility as an external affair (Birch, 2001; see also Logan et al., 1997; McIntosh et al., 1998). CC, from the perspective of those authors, is an extension to a very selectively defined view of CSR, as the book by Sundar from an Indian perspective quite powerfully shows (see Sundar, 2000).

From the analysis of the current academic thinking on CC, it would appear that this is really just a rebranding or relaunch of extant ideas in order to appeal better to business. After all, there seems to be nothing in the CC literature which is significantly different from the traditional CSR stance, except that it lacks any explicit normative aspect. In the limited view, $\mathrm{CC}$ is at most nothing more than a slightly more strategic approach to philanthropy - as when Smith (1994) refers to $\mathrm{CC}$ as "the new corporate philanthropy". In the equivalent view, CC is principally about either rebranding CSR or turning CSR into CSP. We would suggest that such developments to incorporate the business case were already underway in the CSR literature anyway. Not surprisingly, such use of CC has led to a good deal of scepticism about the term being a mere management fad or fashion. More importantly though, the notion of citizenship when applied to corporations also serves to mask emerging shifts in business society relations. In order to show this, we have developed what we call an "extended" view of CC.

\section{Extended view of corporate citizenship}

Finally, it also possible to discern some hints of an extended view of $\mathrm{CC}$ that goes beyond these conceptions rooted in CSR. Whilst there has been only very limited discussion of this perspective directly in relation to $\mathrm{CC}$, it has been alluded to in several recent articles, including those by Van Luijk (2001), Windsor (2001), Wood and Logsdon (2001) and Logsdon and Wood (2002). In the following sections, we attempt therefore to draw also on a broader range of literature from management, political theory and sociology in order to set out a more complete conceptualisation of an extended view of CC, as well as to examine its implications for business-society relations.

\section{"Citizenship" as a core element of corporate citizenship}

In the vast and growing debate on CC there are only very few authors ${ }^{1}$ who deliberately conceptualise the notion of citizenship (cf. Wood and Logsdon, 2001). The majority of authors do 
not move beyond a conventional idea of citizenship that "implies membership in a bounded political (normally national) community" (Hettne, 2000 , p. 35). CC, following this idea, means that corporations are "legal entities with rights and duties, in effect, 'citizens' of states within they operate" (Marsden, 2000, p. 11; see also the title of Seitz, 2002 which is symptomatic of authors in the business community). Although this is a notion of citizenship at the forefront of the discussion of the "European State", the onedimensional and direct application to corporations appears to be more than odd.

To really get behind what could be meant by $\mathrm{CC}$, it is important to have a closer look at citizenship from a perspective that is informed by social sciences, especially political theory. The superficiality of the current reception of the notion of "citizenship" in the management literature on CC is largely a result of a nearly total neglect of interdisciplinary research into the concept. Looking back into the intellectual legacy of citizenship, we could start with Aristotle, who saw citizenship as the "right to participate in the public life of the state, which was more in the line of a duty and a responsibility to look after the interest of the community" (Eriksen and Weigård, 2000, p. 15). Examining corporate citizenship from this perspective, the usage of the term - at least in a direct sense - seems somewhat inappropriate. These rights of political participation were only assigned to individuals. Though there might be a broader application of these rights to corporations there is no real reason to use the term citizenship to indicate activities such as "avoidance of undue influences" through bribery, or "lobbying and other political action" (cf. Wood and Logsdon, 2001, p. 101).

The picture does not get any clearer if we scrutinize the dominant understanding of citizenship in most industrialized societies. In the liberal tradition, citizenship is defined as a set of individual rights (Faulks, 2000, pp. 55-82). Following the still widely accepted categorisation by T. H. Marshall, liberal citizenship comprises three different aspects of entitlement: civil rights, social rights and political rights (Marshall, 1965). Civil rights consist of those rights which provide freedom from abuses and interference by third parties (most notably the government); among the most important ones are the right to own property, to engage in "free" markets or freedom of speech. Social rights consist of those rights which provide the individual with the freedom to participate in society, such as the right to education, healthcare or various aspects of welfare. Both types of rights are clearly focusing on the position of the individual in society and help to protect its status (Eriksen and Weigård, 2000). As such, civil and social rights are to some extent extremes on the same continuum: civil, sometimes called "negative", rights protect the individual against the interference of stronger powers; social, "positive", rights are entitlements towards third parties. The key actor here is the government, which on the one hand respects and grants the civil rights of the "citizens" and - generally by the institutions of the welfare state - cares for the fulfilment and protection of social rights. In contrast to these more passive rights (with the government as active respecter or facilitator) the third category of political rights moves beyond the mere protection of the individual's private sphere towards his or her active participation in society, which therefore takes in a special position (Habermas, 1996). Political rights include the right to vote or the right to hold office and, generally speaking, enable the individual to take part in the process of collective will formation beyond the sphere of his or her own privacy.

If we analyse the term "citizenship" from this perspective it is, at first glance, somewhat hard to make any sense of something like "corporate citizenship" at all. Civil rights, of course, count among the main conditions for modern capitalism as they allow individuals to engage in free markets, own and accumulate property etc. One might even argue that some of these civil rights are also granted to corporations as artificial, legal personalities. This becomes more problematic in the area of social rights: none of these rights in the direct sense can be regarded as an entitlement for a corporation. The only (indirect) role corporations have in these rights is that governments, in protecting social rights, have sometimes significantly restricted the civil rights of individuals (or their business activities). The same applies 
to the political rights: as already discussed above in the Aristotelian context, political rights in the direct sense do not belong to corporations in democratic societies.

Wood and Lodgson (2001), whom we have quoted above as the only other authors who explicitly link their concept of CC to the notion of citizenship now proceed from this understanding of citizenship (which they call a "minimalist view") and gradually loosen the concept of citizenship by introducing other contemporary normative notions of citizenship, such as the communitarian or the human rights view. In so doing, citizenship is not confined to rights only, but includes the respective duties as well. Corporations then enter the picture - not because they have an entitlement to certain rights as a "real" citizen would, but as powerful public actors which have a responsibility to respect those "real" citizen's rights in society. Inevitably therefore, we see a tendency to collapse back into more conventional perspectives on $\mathrm{CC}$, albeit by referring to a new normative concept of citizenship such as the communitarian approach.

It is our intention, however, to proceed differently and analyse these changes from a descriptive perspective. Clinging to the liberal view of citizenship, which at least officially dominates most modern societies (Hindess, 1993), we want to further establish the relation of corporations and citizenship in the context of contemporary Western societies. By this we want to show that $\mathrm{CC}$ is not a view of business and society relations which might (or might not) be adopted by certain voluntary actors (such as a "communitarian" view). We argue that because of elements of institutional failure crucial to the functioning of the notion of liberal citizenship, corporate involvement in "citizenship" moves from a voluntary form of behaviour to an unavoidable occurrence which ultimately results in a necessary reconceptualization of business-society relations.

\section{The decline of liberal citizenship}

The pivotal actor within the liberal view of citizenship is typically the state, or more precisely, the governmental institutions of the nation state (Hettne, 2000). The state is usually expected to protect civil rights, to run the welfare state in order to protect social rights, and the nation state is the arena in which political rights are exercised and collective decisions are taken within the legitimate procedural framework. The crucial point is therefore that citizenship is inseparably linked to a certain (national) territory, which is governed by a sovereign state as ultimate guarantor of citizenship and the rights it embodies.

The decisive step towards a notion of citizenship, which ultimately allows the extension towards a conceptualization of $\mathrm{CC}$, centres around the proposition that nation states increasingly fail to provide this variety of civil rights, resulting in the decline of the role of state. The main reason for this proposed decline of citizenship (at least in the sense of the liberal view commonly shared by most Western democracies) lies in the process of globalization (Falk, 2000). The rights embodied in the traditional concept of citizenship are linked to the state which is sovereign in its own territory. The central characteristic of globalization though consists in the deterritorialization of social, political and economic interaction (Scholte, 2000). This means that a growing number of social activities appear to be taking place beyond the power and influence of the nation state.

In the context of this paper, we would posit globalization as the main eroding factor of citizenship (similarly Logsdon and Wood, 2002). This is not only a reflection of the recent debate in political theory (cf. Turner, 2000), but crucially, globalization also seems to be one of the triggers for the heightened attention to $\mathrm{CC}$ in the business community (see World Economic Forum, 2002). This is not a new observation, and has been scrutinised from a variety of perspectives. Most notably, this phenomenon has been included in current sociological debates. As Beck, Giddens and others have pointed out in the context of risk, the state has proved to be unable to protect its citizens' rights in the face of new social and environmental threats (Beck et al., 1994; Beck, 1997). Without discussing the variety of reasons for this failure, Beck has linked his work closely to the globalization 
debate (Beck, 2000), and can be seen to have identified changes that are crucial underpinnings for our argument. First, there is a definite end to a political setting where the state and its governance structure is the only arena where political action takes place: "the equation of politics and the state", Beck argues, is a "modernist category error" (Beck, 1997, p. 98). Second, and as a direct consequence, we also witness manifestations of politics that "breaks open and erupts beyond the formal responsibilities and hierarchies" (Beck, 1997, p. 99). This new political arena, labelled "subpolitics" by Beck, is clearly visible in the context of globalization and citizenship. As globalization has occurred in the business arena, similar globalization has occurred in the civil arena. There has been the emergence and growth of global NGOs and other civil society actors such as Greenpeace, Amnesty International who advocate the protection of civil and social rights where nation states are either unwilling, have failed, or have been unable to intervene.

\section{Corporations as major players in a framework of dissolving liberal citizenship}

Where do corporations fit into this picture? Our central argument is that corporations enter the arena of citizenship at the point of government failure in the protection of citizenship. More precisely, we suggest that they partly take over those functions with regard to the protection, facilitation and enabling of citizen's rights - formerly an expectation placed solely on the government. We thus argue that if a term such as "corporate citizenship" makes any sense in the proper meaning of the term, "corporations" and "citizenship" in modern society come together at exactly the point where the state ceases to be the only guarantor of citizenship any longer. Seen in another light, it could be hypothesized that corporations are compensating or correcting for government failure. Let us consider some empirical examples.

First, in the area of social rights, it is clear that when analyzing the literature on $\mathrm{CC}$, and especially looking at initiatives from the business community, the majority of $\mathrm{CC}$ targets those "positive" rights where governmental actors fail (for typical areas see Habisch, 2003, pp. 85-139). Foremost, there is the general role of corporations as employers, which is the basis of a variety of functions of the welfare state. However, some of the more philanthropic activities, such as employee volunteering, and charitable acts such as feeding homeless people, helping headmasters in managing school budgets, or improving deprived neighbourhoods, are all activities where business has focused on protecting social rights which originally would have been the task of government.

Ironically, this role of corporations is a direct consequence of the neo-liberal revolution of the 1980 s, where the welfare state was decisively cut back and government drew back from many of its economic functions in order to facilitate a greater variety and intensity of civil rights, such as those embodied in the "free" market and other individual freedom to all sorts of economic activities. Therefore in the industrialized world, it can be argued that CC consists of a partial attempt, motivated by self-interest, to take over those unserved governmental functions that were the result of a cutback in social rights two decades ago.

The situation looks significantly different in developing countries where governments simply cannot afford a welfare state. Improving working conditions in sweatshops, ensuring employees a living wage, providing schools, medical centres and roads, or even providing financial support for the schooling of child labourers are all activities in which corporations such as Shell, Nike, Levi Strauss and others have engaged under the label of CC. In fact, citizenship again means here that corporations take over those functions which are clearly governmental functions in the framework of liberal citizenship.

Second, in the area of civil rights, most developed countries provide their citizens with a fairly reasonable protection of their civil rights. Governmental failure however again becomes visible in developing or transforming countries. Drastic examples, such as the role of Shell in Nigeria and its apparent role in the restriction of civil rights of the Ogoni people (see Wheeler 
et al., 2002), show that corporations might play a crucial role in either discouraging (as Shell) or encouraging governments to live up to their responsibility in this arena of citizenship.

Thirdly, in the area of political rights, the aforementioned argument already seems to suggest that corporations themselves assume some political rights if they take in such a pivotal role in granting and facilitating major rights linked to citizenship. Furthermore, corporations are taking an increasingly active role in the political arena (Schneidewind, 1998). Corporate influence through lobbying, party funding and other activities to influence the political process has grown increasingly, and has put corporations as a more or less officially accepted player in the arena of political rights. This is particularly striking when we look at how the individual citizen seeks to exercise their political rights. Voter apathy in national elections has been widely identified in many industrialized countries (Hertz, 2001), yet there appears to be a growing willingness on the part individuals to participate in political action aimed at corporations rather than at governments. An example of this is when Greenpeace activists Helen Steel and Dave Morris (the McLibel Two, see Vidal, 1997) sought to draw attention to various political issues such as import tariffs, cultural homogenisation, environmental protection and union rights, they achieved international coverage for their efforts not by tackling the French or the U.K. governments, but by attacking the McDonald's corporation.

\section{Conclusion}

The enthusiastic adoption of the term CC in the business world can be viewed in a positive light, and in a sense business is taking ownership of a term that they themselves shape, and mould into a concept of business and society. However, from an academic perspective, the change in terminology to $\mathrm{CC}$ is equivocal. On the one hand, $\mathrm{CC}$ as understood within the two conventional perspectives appears to provide little of substance to the debate on business-society relations - and insofar as it contributes to conceptual confusion, may even be counter-productive. Conversely, in the light of the extended theoretical perspective, there appears to be significant relevance for the adoption and reconceptualisation of the social role and responsibilities of business in the framework of CC. However, this perspective could be significantly different from the practitioner interpretation of CC. This raises some important issues.

First, by stepping outside of the boundaries of business ethics, and drawing on broader notions of citizenship, the implications for business and society relations are far more than the idea that corporations have discovered their "place in society", in a cosy harmonious co-existence with their "fellow citizens" living up to a vision of citizenship including both a mixture of fair rights and responsibilities. Behind this mask of CC, our analysis suggests quite a different face: apart from small and medium sized enterprises, who because of their size and level of social embeddedness could be viewed on a closer level to "private" citizens, large corporations do not share a similar status of citizenship as individuals. Thus, "corporate" citizenship could imply a substantially different notion. Citizenship is a bundle of more or less well defined rights, and the corporate involvement in this context does not mean that corporations bravely share in these, but that they have gradually amounted to replace the most powerful institution in the traditional concept of citizenship, namely Government. Corporations, and to a decreasing amount governmental institutions, assume responsibility for the protection and facilitation of social, civil and political rights and corporate "citizenship", we would suggest, can and should be reconceptualized to mean exactly this. The implications are that corporations are engaging as facilitators of the citizen process, regardless of whether they are explicitly setting out to be "good corporate citizens".

This finding is even less surprising when the implications of power are brought into the $\mathrm{CC}$ argument. Traditional models of citizenship imply being a member of a democratic society, with equal political, civil and social rights, with equal power. It seems inappropriate to apply these traditional models of citizenship to corporations, as although the concepts of political, civil and social rights (and responsibilities) can be 
stretched to fit the corporate case, the underlying fact is that corporations possess considerable power over and above the average citizen. Corporations are economic institutions, which are reliant on citizens, but cannot be classed as citizens themselves. If CC represents participation in society, it makes sense that business fulfils a role similar to that of government rather than the average citizen.

This leads to another observation: corporate "citizens" normally assume their role only if it is in their self-interest to do so. This leads to activities of CC that are often, but certainly not always, praiseworthy and for the benefit of society. If governments fail in their responsibility to facilitate citizenship, society can only be happy if this gap is filled by corporations. But should society really be entirely happy about this? The immediate question is: if corporations have assumed such a pivotal and powerful role in society, what happens if CC - in its extended sense - is not in their self-interest? The question leads to a more general, and in fact more fundamental problem connected to CC: if corporations take over vital functions of governments, they should take over to the same degree exactly the type of accountability which modern societies demand from government as a facilitator of citizen rights. Governments are accountable to their citizens and, in principle, could be approved or discharged of their responsibilities through the electoral process. Similar mechanisms however do not yet exist with regard to corporations. $C C$ in this light is far more than a new brand of CSR, or a fad in describing business and society relations - it is taking the roles and responsibilities of business into a whole new area. Corporations are left to protect (or when it is not in their own self-interest, to not protect) certain rights for consumers, workers and other citizens even if it doesn't come under the explicit heading of "Corporate Citizenship". It identifies a shift in the corporate role of society that puts the question of corporate accountability up to the top of the social, political and economic agenda of societies in the age of globalization. From this perspective, rather than being, as many have claimed, the solution to urgent problems (e.g. Habisch et al., 2001, p. 1), CC in its more mean- ingful sense, is in fact just as much the urgent problem itself.

\section{Note}

1 One of the few contributions reflecting the explicit notion of "citizenship" in Europe is a recent book by Seitz (2002). However, his translation of "citizenship" by the German "Bürgerschaft" shows the traps and pitfalls of a politically uninformed approach to the term. As Eriksen and Weigård (2000) stress, the German "Bürger" (or the Scandinavian equivalent "borger") includes both the English/French notion of "citizen/citoyen" and "bourgeois". Whereas the first mainly reaches back to the Aristotelian notion of citizenships as a set of rights and duties in political participation (a limitation clearly reflected by Seitz' work), only the second extends the perspective and finally leads to the integrative perspective of liberal citizenship in the Marshallian sense, which is the dominant pattern of citizenship on Western democracies today.

\section{References}

Andriof, J. and M. McIntosh: 2001, 'Introduction', in J. Andriof and M. McIntosh (eds.), Perspectives on Corporate Citizenship (Greenleaf, Sheffield), pp. 13-24.

Beck, U., A. Giddens and S. Lash: 1994, Reflexive Modernization (Stanford University Press, Stanford).

Beck, U.: 1997, The Reinvention of Politics (Polity Press, Cambridge).

Beck, U.: 2000, 'Risk Society Revisited: Theory, Politics and Research Programmes', in U. Beck, B. Adam and J. Van Loon (eds.), The Risk Society and Beyond - Critical Issues for Social Theory (Sage, London), pp. 211-229.

Birch, D.: 2001, 'Corporate Citizenship - Rethinking Business Beyond Corporate Social Responsibility', in J. Andriof and M. McIntosh (eds.), Perspectives on Corporate Citizenship (Greenleaf, Sheffield), pp. 53-65.

Bolino, M., W. Turnley and J. Bloodgood: 2002, 'Citizen Behaviour and the Creation of Social Capital in Organisations', Academy of Management Review 27(4), 505-522.

Burke, L. and J. M. Logsdon: 1996, 'How Corporate Social Responsibility Pays Off', Long Range Planning 29(4), 495-502. 
Carroll, A. B.: 1979, 'A Three Dimensional Model of Corporate Social Performance', Academy of Management Review 4, 497-505.

Carroll, A. B.: 1991, 'The Pyramid of Corporate Social Responsibility: Toward the Moral Management of Organizational Stakeholders', Business Horizons 34(4), 39-48.

Carroll, A. B.: 1998, 'The Four Faces of Corporate Citizenship', Business and Society Review 100(1), 1-7.

Carroll, A. B.: 1999, 'Corporate Social Responsibility - Evolution of a Definitional Construct', Business E Society 38(3), 268-295.

Carroll, A. B. and A. K. Buchholtz: 2000, Business $\mathcal{E}$ Society, 4th edition (Thomson Learning, Cincinnati).

Davenport, K.: 2000, 'Corporate Citizenship: A Stakeholder Approach for Defining Corporate Social Performance and Identifying Measures for Assessing It', Business \& Society 39(2), 210-219.

Donaldson, T. and L. E. Preston: 1995, 'The Stakeholder Theory of the Corporation: Concepts, Evidence, and Implications', Academy of Management Review 20(1), 65-91.

Eriksen, E. and J. Weigård: 2000, 'The End of Citizenship?', in C. McKinnon and I. HampsherMonk (eds.), The Demands of Citizenship (Continuum, London), pp. 13-24.

Evan, W. M. and R. E. Freeman: 1993, 'A Stakeholder Theory of the Modern Corporation: Kantian Capitalism', in T. L. Beauchamp and N. E. Bowie (eds.), Ethical Theory and Business, 3rd edition (Prentice-Hall, Englewood Cliffs/NJ).

Falk, R.: 2000, 'The Decline of Citizenship in an Era of Globalization', Citizenship Studies 4(1), 5-17.

Faulks, K.: 2000, Citizenship (Routledge, London).

Fombrun, C. J., N. A. Gardberg and M. L. Barnett: 2000, 'Opportunity Platforms and Safety Nets: Corporate Citizenship and Reputational Risk', Business and Society Review 105(1), 85-106.

Freeman, R. E.: 1984, Strategic Management. A Stakeholder Approach (Pitman, Boston).

Gibson, K.: 2000, 'The Moral Basis of Stakeholder Theory', Journal of Business Ethics 26, 245-257.

Habermas, J.: 1996, Between Facts and Norms (MIT Press, Cambridge/MA).

Habisch, A., H. P. Meister and R. Schmidpeter: 2001, Corporate Citizenship as Investing in Social Capital (Logos, Berlin).

Habisch, A.: 2003, Corporate Citizenship. Gesellschaftliches Engagement von Unternehmen in Deutschland (Springer, Berlin/Heidelberg).
Hertz, N.: 2001, 'Better to Shop than to Vote?', Business Ethics: A European Review 10(3), 190-193.

Hettne, B.: 2000, 'The Fate of Citizenship in PostWestphalia', Citizenship Studies 4(1), 35-46.

Hindess, B.: 1993, 'Citizenship in the Modern West', in Brian S. Turner (ed.), Citizenship and Social Theory (Sage, London), pp. 19-35.

Logan, D., D. Roy and L. Regelbrugge: 1997, Global Corporate Citizenship - Rationale and Strategies (Hitachi Foundation, Washington DC).

Logsdon, J. M. and D. J. Wood: 2002, 'Business Citizenship: From Domestic to Global Level of Analysis', Business Ethics Quarterly 12(2), 155-188.

Maignan, I., O. C. Ferrell and G. T. M. Hult: 1999, 'Corporate Citizenship: Cultural Antecedents and Business Benefits', Journal of the Academy of Marketing Science 27(4), 455-469.

Maignan, I. and O. C. Ferrell: 2000, 'Measuring Corporate Citizenship in Two Countries: The Case of the United States and France', Journal of Business Ethics 23, 283-297.

Maignan, I. and O. C. Ferrell: 2001, 'Antecedents and Benefits of Corporate Citizenship: An Investigation of French Businesses', Journal of Business Research 51, 37-51.

Marsden, C.: 2000, 'The New Corporate Citizenship of Big Business: Part of the Solution to Sustainability', Business and Society Review 105(1), 9-25.

Marshall, T. H.: 1965, Class, Citizenship and Social Development (Anchor Books, New York).

McWilliams, A. and D. Siegel: 2000 'Corporate Social Responsibility and Financial Performance: Correlation or Mispecification', Strategic Management Journal 21, 603-609.

McIntosh, M., D. Leipziger, K. Jones and G. Coleman: 1998, Corporate Citizenship: Successful Strategies for Responsible Companies (Financial Times/Pitman, London).

Pinkston, T. S. and A. B. Carroll: 1994, 'Corporate Citizenship Perspectives and Foreign Direct Investment in the US', Journal of Business Ethics 13, 157-169.

Schneidewind, U.: 1998, Die Unternehmung als strukturpolitischer Akteur (Metropolis, Marburg).

Scholte, J. A.: 2000, Globalization. A Critical Introduction (Palgrave, Basingstoke).

Seitz, B.: 2002, Corporate Citizenship. Rechte und Pflichten der Unternehmung im Zeitalter der Globalität (Deutscher Universitäts-Verlag, Wiesbaden).

Smith, C.: 1994, 'The New Corporate Philanthropy', Harvard Business Review 72(3), 105-116.

Stroup, M. A. and R. L. Neubert: 1987, 'The 
Evolution of Social Responsibility', Business Horizons (March-April), 22-24.

Sundar, P.: 2000, Beyond Business - from Merchant Charity to Corporate Citizenship. Indian Business Philanthropy through the Ages (Tata McGraw-Hill, New Delhi).

Turner, B. S.: 2000, 'Review Essay: Citizenship and Political Globalization', Citizenship Studies 4(1), 81-86.

Ulrich, P.: 2000, Repulikanischer Liberalismus und Corporate Citizenship (Nr. 88 Berichte des Insitituts für Wirtschaftsethik der Universität St. Gallen, St. Gallen).

Van Luijk, H. J. L.: 2001, 'Business Ethics in Europe: A Tale of Two Efforts', in Reinhart Lang (ed.), Wirtschaftsethik in Mittel- und Osteuropa (Rainer Hampp, Munich), pp. 9-18.

Vidal, J.: 1997, McLibel (Macmillan, London).

Waddell, S.: 2000, 'New Institutions for the Practice of Corporate Citizenship: Historical, Intersectoral, and Developmental Perspectives', Business and Society Review 105(1), 107-126.

Waddock, S.: 2001, 'The Multiple Bottom Lines of Corporate Citizenship: Social Investing, Reputation, and Responsibility Audits', Business and Society Review 105(3), 323-345.

Warhurst, A.: 2001, 'Corporate Citizenship as Corporate Social Investment', Journal of Corporate Citizenship 1, 57-73.

Wartick, S. L. and P. L. Cochran: 1985, 'The Evolution of the Corporate Social Performance Model', Academy of Management Review 10, 758-769.

Wheeler, D., H. Fabig and R. Boele: 2002, 'Paradoxes and Dilemmas for Stakeholder Responsive Firms in the Extractive Sector: Lessons from the Case of Shell and the Ogoni', Journal of Business Ethics 38, 297-318.

Wijnberg, N. M.: 2000, 'Normative Stakeholder Theory and Aristotle: The Link between Ethics and Politics', Journal of Business Ethics 25, 329-342.

Windsor, D.: 2001, 'Corporate Citizenship: Evolution and Interpretation', in J. Andriof and $M$. McIntosh (eds.), Perspectives on Corporate Citizenship (Greenleaf, Sheffield), pp. 39-52.

Wood, D. J.: 1991, 'Corporate Performance Revisited', Academy of Management Review 16(4), 691-718.

Wood, D. J. and J. M. Logsdon: 2001, 'Theorising Business Citizenship', in J. Andriof and $M$. Mclntosh (eds.), Perspectives on Corporate Citizenship (Greenleaf, Sheffield), pp. 83-103.

World Economic Forum: 2002, Global Corporate Citizenship: The Leadership Challenge for CEOs and Boards (World Economic Forum and The Prince of Wales Business Leaders Forum, Geneva).

Dirk Matten

International Centre for Corporate Social Responsibility,

Nottingham University Business School, Jubilee Campus, Wollaton Road, Nottingham NG8 1BB, $U . K$.

E-mail:Dirk.Matten@nottingham.ac.uk 
Copyright of Journal of Business Ethics is the property of Springer Science \& Business Media B.V. and its content may not be copied or emailed to multiple sites or posted to a listserv without the copyright holder's express written permission. However, users may print, download, or email articles for individual use. 